\title{
UJI TINGKAT KEMATANGAN BUAH MANGGA MENGGUNAKAN PIGMEN ANTOSIANIN DARI BUNGA TELANG (Clitoria ternatea)
}

\author{
Dhanang Puspita ${ }^{1)}$, Monang Sihombing ${ }^{1)}$, Karina Permata ${ }^{1)}$ \\ Teknologi Pangan, Universitas Kristen Satya Wacana
}

Email: ${ }^{1)}$ dhanang.puspita@uksw.edu

\section{Diterima 7 Agustus 2021 disetujui 20 September diterbitkan 30 November 2021}

\begin{abstract}
Increased consumption of fruit requires consumers to understand how to choose good and ripe fruit. The level of fruit maturity can be known based on physical characteristics, including the parameters of size, weight, skin color, fragrance of the fruit, and the level of hardness of the fruit flesh. Determining the level of fruit maturity based on physical characteristics has a weakness that is subjective and inconsistent. Making indicators based on natural dyes, namely anthocyanins, to determine the level of sweetness of the fruit. The purpose of this research is to use anthocyanin pigments as an indicator of fruit sweetness level to determine fruit maturity. This research is an experimental laboratory and qualitative descriptive analysis with stages; Sample Extraction, Indicator Making, Indicator Application, Fruit Acidity Testing, Data Analysis. Based on the results of the study, there were quite visible color differences on toothpicks after being inserted into the fruit samples with a sweet taste and the fruit samples with a sour taste. The indicator shows that fruit with a sour taste $(\mathrm{pH}<3)$ changes color from blue to reddish purple. If the taste is not too sour ( $\mathrm{pH} 5$ ), it does not experience a significant color change. In conclusion, the anthocyanins in telang flower can be used as an indicator solution because they have a blue color at neutral $\mathrm{pH}$, a reddish color at $\mathrm{pH}=2$, the red color fades at $\mathrm{pH}=3$ and 4, and there is no color change at $\mathrm{pH} 5$.
\end{abstract}

Keywords: anthocyanins, telang flower, pigment.

\section{PENDAHULUAN}

Pada akhir tahun 2019 ditemukan virus varian baru yang berasal dari daratan Tiongkok yang diberi nama SARS-COV2 atau umumnya dikenal dengan nama virus Covid-19. Penyebaran Covid-19 yang masif dan dampak buruknya bagi kesehatan, menyebabkan menjadi pandemi. Kondisi pandemi secara langsung memberikan perubahan terhadap gaya hidup masyarakat, salah satunya terjadi perubahan pada pola makan. Kementerian Kesehatan RI (2020) menghimbau masyarakat untuk dapat mengonsumsi makanan bergizi seimbang yang mengandung Vitamin A, C, E, dan Zink guna meningkatkan daya tahan tubuh yang mana bisa diperoleh dari konsumsi sayur dan buah-buahan.

Selama masa pandemi Covid-19 telah terjadi peningkatan tren di masyarakat untuk mengonsumsi bahan pangan alami yang memiliki manfaat fungsional bagi tubuh namun rendah karbohidrat, rendah lemak, dan rendah gula. Berdasarkan data Humas Kementerian Koordinator Bidang Perekonomian RI (2020) pada bulan JanuariMei 2020 terjadi peningkatan permintaan terhadap buah-buahan dari pasar global secara tajam yaitu mencapai $31,89 \%$.

Pada penelitian yang telah dilakukan oleh Ritongga (2021) masa pandemi juga menyebabkan terjadi peningkatan pembelian buah melalui e-commerce di Kota Medan. Peningkatan konsumsi buah mengharuskan konsumen dapat mengerti cara memilih buah yang baik dan matang. Tingkat kematangan buah dapat diketahui berdasarkan karakteristik fisik, yaitu ukuran, berat, warna kulit, keharuman dari buah, dan tingkat kekerasan daging buah. Faktor atribut yang mempengaruhi konsumen dalam membeli buah adalah rasa yang manis, kesegaran 
buah, kandungan vitamin, ukuran dan harga (Muzdalifah, 2012).

Buah yang memiliki rasa yang asam kurang digemari jika disajikan sebagai buah meja. Parameter untuk menentukan kematangan buah secara visual tidak dapat memberikan informasi kepada konsumen mengenai rasa buah, selain itu terdapat banyak kelemahan terhadap persepsi kematangan buah karena penilaian konsumen yang menggunakan indera penglihatan dan peraba sebagai penentu tingkat kematangan bersifat subyektif dan tidak konsisten.

Menurut Nurdayati (2016) mutu buah yang baik diperoleh jika buah dipanen saat sudah tua atau sudah matang. Buah yang dipanen sebelum waktunya masak akan menghasilkan mutu yang kurang baik Sebaliknya juga, apabila melakukan penundaan pemetikan akan meningkatkan kepekaan buah terhadap kerusakan. Salah satunya adalah buah mangga, jika dipanen sebelum waktunya maka buah mangga masih terasa asam setelah diperam walaupun warna kulitnya sudah terlihat matang.

Perkembangan jaman yang diikuti dengan perkembangan teknologi informasi memungkinkan konsumen untuk dapat mendeteksi tingkat kemanisan buah dengan bantuan indikator. Penelitian mengenai proses pematangan dan penentuan tingkat kemanisan buah telah banyak dilakukan, akan tetapi penelitian-penelitian sebelumnya tidak dapat memberikan informasi mengenai tingkat kematangan yang berkorelasi dengan tingkat kemanisan buah secara langsung atau dengan waktu yang singkat.

Penelitian yang telah dilaksanakan terkait penentuan tingkat kemanisan buah oleh Ihsan \& Wahyudi (2010) mengenai teknik analisis kadar sukrosa pada buah pepaya menggunakan refraktometer. Refraktometer merupakan alat yang dapat digunakan untuk menganalisis kadar sukrosa pada bahan makanan berdasarkan kandungan padatan terlarut dengan satuan skala pembacaan yaitu ${ }^{\circ}$ Brix. Pengukuran menggunakan alat ukur refraktometer memerlukan keahlian khusus serta harus merusak buah itu sendiri. Buah perlu dikupas, dipotong, dilebur agar menjadi lebih cair yang mana menggunakan sampel dengan jumlah lebih banyak. Pengujian memakan waktu yang lebih lama dan alat yang digunakan cukup mahal.

Penelitian mengenai pembuatan indikator telah dilaksanakan oleh Yulianti (2019) mengenai pengujian kualitatif boraks pada bakso dengan indikator alami dari ekstrak bunga telang. Indikator alami yaitu ekstrak bunga telang dimanfaatkan karena mengandung pigmen antosianin yang sensitif terhadap perubahan $\mathrm{pH}$. Antosianin akan berubah warna menjadi merah pada $\mathrm{pH}$ asam dan menjadi biru pada $\mathrm{pH}$ basa. Berdasarkan penelitian yang telah dilakukan oleh Yulianti (2019) memberikan informasi bahwa antosianin dari bunga telang dapat memberikan perubahan warna signifikan terhadap perubahan derajat keasaman. Pembuatan indikator berbahan dasar pewarna alami yaitu antosianin untuk mengetahui tingkat kemanisan buah menarik untuk dilakukan sebagai penelitian lanjutan. Tujuan dilakukan penelitian ialah pemanfaatan pigmen antosianin sebagai indikator tingkat kemanisan buah untuk mengetahui kematangan buah.

\section{METODE}

\section{Waktu dan Tempat}

Penelitian ini dilakukan di laboratorium food processing dan laboratorium biokimia, Fakultas Kedokteran dan Ilmu Kesehatan, Universitas Kristen Satya Wacana. Penelitian ini laksanakan pada bulan Agustus 2021.

\section{Alat dan Bahan}

Alat yang digunakan antara lain; timbangan pocket scale analitik 0,01 gram, heater elektrik (Goto), pisau dan saringan. Bahan yang digunakan dalam penelitian ini terdiri atas bunga telang kering, buah mangga, pH-strip paper litmus box, dan tusuk gigi.

\section{Ekstraksi Sampel (Fanany, 2020)}

Sebanyak $15 \mathrm{~g}$ sampel bunga telang kering dimaserasi menggunakan aquades 
dengan rasio perbandingan bahan : pelarut adalah 1 : 40 dipanaskan selama 180 menit pada suhu $50^{\circ} \mathrm{C}$.

Pembuatan Indikator (Supardan, 2020)

Tusuk gigi direndam dengan larutan ekstraksi bunga telang yang telah disaring selama kurang lebih 24 jam kemudian tusuk gigi dikeringkan dengan diangin-anginkan dan tidak boleh terkena sinar matahari langsung

\section{Aplikasi Indikator}

Tusuk gigi yang sudah kering ditusukan kedalam sampel buah selama kurang lebih 30 detik. Amati perubahan warna yang terjadi pada tusuk gigi. Tusuk gigi dipilih sebagai indikator karena memiliki daya serap yang baik sehingga pigmen antosianin dari bunga telang dapat terserap dan melapisi bagian terluar tusuk gigi, selain itu tusuk gigi memberikan pengaruh kerusakan dengan luas permukaan yang tidak terlalu besar sehingga meminimalkan terjadi kontaminasi dan proses pembusukan secara cepat.

\section{Pengujian Derajat Keasaman Buah}

Sampel buah dipotong menggunakan pisau kemudian tempelkan $\mathrm{pH}$-strip pada daging buah mangga dengan berbagai tingkat kematangan dan varietas, kemudian amati perubahan warna dan sesuaikan dengan trayek warna perubahan $\mathrm{pH}$-strip

\section{Analisa Data}

Data yang di peroleh adalah hasil perubahan warna indikator antosianin terhadap tingkat kemanisan buah. Analisa dilakukan secara deskriptif-kualitatif yaitu berdasarkan perubahan warna indikator terhadap tingkat kemanisan buahmenggunakan pendekatan fenomenologi untuk menyelidiki fenomena masyarakat adat Kampung Kuta dalam memanfaatkan cuka aren sebagai pengobatan tradisional. Teknik analisis data menggunakan model Miles and Huberman meliputi reduksi data, penyajian data dan penarikan kesimpulan/verifikasi (Sugiyono, 2016).

\section{HASIL DAN PEMBAHASAN}

Berdasarkan pada hasil penelitian, terdapat perbedaan warna yang cukup terlihat pada tusuk gigi setelah ditusukan kedalam sampel buah dengan rasa manis dan sampel buah dengan rasa asam. Pada pengujian pertama menggunakan sampel buah yang memiliki tingkat kematangan yang berbeda yaitu matang penuh dan mentah untuk mengetahui perbedaan perubahan warna pada indikator tusuk gigi. Sampel buah buah mangga dipilih berdasarkan karakteristik tingkat kematangan buah, yaitu aroma, tingkat kekerasan dan warna kulit. Sampel buah mangga mentah yang dipilih memiliki karakteristik tingkat kekerasan cukup keras, aroma tidak ada dan warna kulit masih hijau. Sampel buah mangga matang memiliki karakteristik yaitu tingkat kekerasan daging buah sudah lunak, memiliki aroma khas dan warna kulit hijau. Buah mangga dipilih sebagai sampel untuk pengujian karena memiliki tingkat kemanisan yang berbeda saat buah sudah matang penuh dan masih mentah. Hasil pengujian tersebut dapat dilihat pada Tabel 1.

Tabel 1. Hasil Pengujian Indikator Tusuk Gigi Pada Buah Mangga Matang dan Mentah

\begin{tabular}{|c|c|c|c|}
\hline Sampel & $\begin{array}{c}\text { Perubahan } \\
\text { Warna Tusuk } \\
\text { Gigi }\end{array}$ & pH & Organoleptik \\
\hline \multirow{3}{*}{$\begin{array}{l}\text { Mangga } \\
\text { Aromanis } \\
\text { Matang }\end{array}$} & Ungu & \multirow[t]{3}{*}{2} & Rasa: sangat \\
\hline & kemerahan & & Asam \\
\hline & & & $\begin{array}{l}\text { Warna daging } \\
\text { buah: kuning } \\
\text { pekat }\end{array}$ \\
\hline Mangga & \multirow{2}{*}{$\begin{array}{l}\text { Ungu sedikit } \\
\text { kemerahan }\end{array}$} & \multirow[t]{2}{*}{3} & \multirow{2}{*}{$\begin{array}{l}\text { Rasa: asam } \\
\text { Warna daging } \\
\text { buah: kuning }\end{array}$} \\
\hline $\begin{array}{l}\text { Aromanis } \\
\text { Mentah }\end{array}$ & & & \\
\hline
\end{tabular}


Antosianin dari ekstrak bunga telang menyebabkan warna biru pada tusuk gigi karena proses perendaman selama 24 jam. Tusuk gigi sebelum ditusukan kedalam sampel memiliki warna biru karena berada dalam suasana $\mathrm{pH}$ netral. Berdasarkan hasil pengujian sampel buah mangga yang mentah maupun sudah masak penuh, keduanya memiliki rasa yang sama yaitu masam. Hal tesebut dapat dilihat dari hasil pengujian pada tusuk gigi. Pada kedua sampel buah mangga yang matang dan mentah, tusuk gigi yang telah ditusukan mengalami perubahan warna dari biru menjadi menjadi kemerahan. Karakteristik fisik kematangan buah tidak dapat membantu untuk menentukan tingkat kemanisan buah tersebut.

Perubahan tingkat keasaman pada buah akan semakin berkurang seiring proses kematangan buah. Asam organik yang terkandung pada buah digunakan sebagai sumber energi cadangan. Apabila terjadi aktivitas metabolisme yang lebih besar, jumlah asam organik akan turun dan hal tersebut terjadi saat proses pematangan berlangsung. Hal tersebut sesuai dengan penelitian yang telah dilakukan oleh Campbell et al, (1999) dalam Rachmayati (2017) mengenai keasaman buah saat matang, yaitu selama proses pematangan buah, buah akan menjadi lebih manis karena terjadi proses hidrolisis asam. Asam organik pada buah akan diubah menjadi gula hingga mencapai proporsi $20 \%$ pada buah yang matang. Proses hidrolisis asam menjadi gula sederhana mengakibatkan ion-ion $\mathrm{H}^{+}$dalam buah akan menurun. Jika proporsi ion $\mathrm{H}^{+}$ lebih besar dari ion $\mathrm{OH}^{-}$maka material tersebut disebut asam yaitu nilai $\mathrm{pH}<7$. Sebaliknya jika proporsi ion $\mathrm{OH}^{-}$lebih besar dari proporsi ion $\mathrm{H}^{+}$maka material tersebut disebut basa yaitu nilai $\mathrm{pH}>7$. Apabila proporsi ion $\mathrm{H}^{+}$sama dengan ion $\mathrm{OH}^{-}$maka material tersebut merupakan material netral.

Pengujian selanjutnya ialah menggunakan buah mangga dengan berbagai jenis varian. Buah mangga dipilih sesuai dengan parameter fisik kematangan buah mangga yaitu bentuk buah yang padat, bekas tangkai sudah kelihatan mengering, daging buah sudah lunak, terdapat bintik-bintik coklat, dan memiliki aroma harum yang khas. Hasil pengujian dapat dilihat pada Tabel 2.

Tabel 2. Hasil Pengujian Indikator Tusuk Gigi Pada Buah Mangga

\begin{tabular}{|c|c|c|c|}
\hline $\begin{array}{l}\text { Sampel } \\
\text { Buah } \\
\text { Mangga }\end{array}$ & $\begin{array}{c}\text { Perubahan } \\
\text { Warna Tusuk } \\
\text { Gigi }\end{array}$ & pH & Organoleptik \\
\hline Golek & Merah muda & 2 & $\begin{array}{l}\text { Rasa: sangat } \\
\text { asam } \\
\text { Warna daging } \\
\text { buah: kuning } \\
\text { pekat }\end{array}$ \\
\hline Jawa & Biru & 5 & $\begin{array}{l}\text { Rasa: manis } \\
\text { hambar } \\
\text { Warna daging } \\
\text { buah: kuning } \\
\text { pekat }\end{array}$ \\
\hline Madu & Biru & 3 & $\begin{array}{l}\text { Rasa: asam } \\
\text { Warna daging } \\
\text { buah: kuning } \\
\text { pucat }\end{array}$ \\
\hline Chokanan & Biru pucat & 5 & $\begin{array}{l}\text { Rasa: manis } \\
\text { Warna daging } \\
\text { buah: kuning }\end{array}$ \\
\hline Cengkir & Biru & 5 & $\begin{array}{l}\text { Rasa: manis } \\
\text { Warna daging } \\
\text { buah: kuning } \\
\text { pekat }\end{array}$ \\
\hline $\begin{array}{l}\text { Arum } \\
\text { Manis } \\
\text { Super }\end{array}$ & Biru kekuningan & 4 & $\begin{array}{l}\text { Rasa: manis } \\
\text { sedikit asam } \\
\text { Warna daging } \\
\text { buah: kuning } \\
\text { pekat }\end{array}$ \\
\hline $\begin{array}{l}\text { Arum } \\
\text { Manis } \\
\text { Biasa }\end{array}$ & Merah & 2 & $\begin{array}{l}\text { Rasa: sangat } \\
\text { asam } \\
\text { Warna daging } \\
\text { buah: kuning }\end{array}$ \\
\hline
\end{tabular}


Perubahan warna pada pengujian Tabel 2. sesuai dengan karakteristik antosianin yaitu akan mengalami degradasi warna menjadi merah jika berada suasana asam kuat. Pada sampel mangga madu, tusuk gigi tidak mengalami perubahan warna. Tusuk gigi seharusnya mengalami perubahan warna dari warna biru menjadi ungu atau ungu kemerahan karena antosianin mengalami berada pada suasana asam $(\mathrm{pH}=$ 3). Mangga madu memiliki kadar air sedang, dibandingkan sampel mangga lainnya. Mangga madu memiliki kandungan kadar air yang lebih sedikit dan tekstur daging buah yang kesat (Pracaya, 2011). Kadar air yang sedikit menyebabkan tusuk gigi tidak dapat menyerap kandungan air pada mangga madu sehingga mengakibatkan tusuk gigi tidak mengalami perubahan warna.

Buah mangga yang sudah matang, jika ditusuk menggunakan indikator tusuk gigi seharusnya tidak mengalami perubahan warna signifikan. Buah mangga yang sudah matang telah mengalami pergeseran $\mathrm{pH}$ dari 2 menjadi 5,5 karena mengalami penurunan asam organik. Asam organik yang mengalami penurunan yaitu asam sitrat, asam malat dan askorbat yang masingmasing nya mengalami penurunan sebesar 10, 40, dan 2,5 kali (Sudjatha dan Wisaniyasa, 2017).

Tusuk gigi dipilih sebagai indikator karena memiliki daya serap yang baik sehingga pigmen antosianin dari bunga telang dapat terserap dan melapisi bagian terluar tusuk gigi, selain itu tusuk gigi memberikan pengaruh kerusakan dengan luas permukaan yang tidak terlalu besar sehingga meminimalkan terjadi kontaminasi dan proses pembusukan secara cepat. Pengaplikasian menggunakan tusuk gigi mudah dilakukan karena tidak memerlukan keterampilan khusus dalam pembuatannya serta mudah ditemukan dan murah.

Antosianin yang telah diserap oleh tusuk gigi akan bereaksi dengan derajat keasaman pada buah, karena antosianin sensitiv terhadap asam (Priska., dkk, 2018). Asam pada buah dapat memberikan pengaruh perubahan warna antosianin pada tusuk gigi, semakin asam buah maka perubahan warna pada tusuk gigi akan semakin terlihat perubahan warnanya dari warna biru menjadi warna merah. Menurut Brouillard (1982) dalam Mahmudatussa'adah, Ai., dkk (2014) antosianin akan berubah warna menjadi merah pada larutan asam. Pada $\mathrm{pH}$ rendah yaitu $\mathrm{pH}=1-2$ akan membentuk kation flavillium yang merupakan bentuk antosianin paling stabil, pada $\mathrm{pH} 3$ kation flavillium ada yang berubah menjadi karbinol yang tidak berwarna maka warna merah antosianin akan memudar, pada $\mathrm{pH}>3$ warna merah terang kation flavylium berubah bentuk menjadi basa kuinonoidal yang berwarna biru atau menjadi karbinol pseudobase yang tidak berwarna sejalan dengan naiknya $\mathrm{pH}$ sampai pH 7 sehingga perubahan warna akan berubah dari merah pudar menjadi merah keunguan kemudian menjadi biru pada $\mathrm{pH}$ netral.

Antosianin pada bunga telang yang digunakan untuk melapisi tusuk gigi memiliki intensitas warna tertinggi pada $\mathrm{pH}$ 7. Meningkatnya suasana asam pada media akan mempercepat degradasi warna dari pigmen bunga telang yang terdapat pada tusuk gigi. Berdasarkan penelitian yang telah dilaksanakan oleh Agrianin (2019) ekstrak bunga telang akan menghasilkan warna merah jambu pada $\mathrm{pH} 1$, warna ungu pada $\mathrm{pH}$ 4, warna biru pada $\mathrm{pH} 7$ dan warna hijau pada $\mathrm{pH}$ 10. Perubahan warna antosianin dapat dilihat pada Gambar 1.

$\begin{array}{llll}\mathrm{pH} 1 & \mathrm{pH} 4 & \mathrm{pH} 7 & \mathrm{pH} 10\end{array}$

Gambar 1. Perubahan Warna Antosianin Bunga Telang Terhadap Pengaruh pH (Agrianin, 2019).

Perubahan warna antosianin bunga telang dan kubis ungu memiliki trayek warna yang sama. Antosianin kubis ungu dan bunga telang pada $\mathrm{pH}$ netral memiliki warna biru. Maka perubahan warna indikator tusuk gigi kurang lebih akan mengalami perubahan yang sama dengan perubahan warna larutan antosianin dari kubis ungu pada berbagai 
derajat keasaman. Perubahan warna antosianin pada berbagai derajat keasaman dapat dilihat pada Gambar 2.

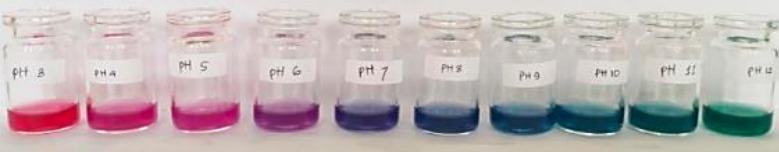

Gambar 2. Perubahan Warna Antosianin Kubis Ungu Terhadap Pengaruh pH (Susanti, dkk. 2019)

Berdasarkan hasil pengujian, indikator menggunakan tusuk gigi yang telah direndam ekstrak antosianin bunga telang dapat dijadikan media untuk mengetahui tingkat kemanisan buah yang mana berkorelasi dengan tingkat kematangan pada buah berdasarkan perubahan warna yang ditimbulkan setelah ditusukan ke dalam daging buah. Tusuk gigi yang ditusukan pada buah dengan rasa asam $(\mathrm{pH}<3)$ mengalami perubahan warna yaitu dari biru menjadi ungu kemerahan. Tusuk gigi yang ditusukan pada buah dengan rasa tidak terlalu asam $(\mathrm{pH}$ $>4$ ) tidak mengalami perubahan warna signifikan. Perubahan warna tusuk gigi menjadi biru kekuningan jika terdapat sedikit rasa asam sementara untuk buah dengan rasa manis, tusuk gigi tetap berwarna biru atau tidak berubah warna.

\section{SIMPULAN}

Antosianin pada bunga telang dapat dimanfaatkan sebagai larutan indikator karena memiliki rentang perubahan warna yang jelas. Indikator tusuk gigi memberikan perubahan warna kemerahan pada $\mathrm{pH}=2$, warna merah semakin memudar pada $\mathrm{pH}=3$ dan 4 , dan tidak terjadi perubahan warna pada $\mathrm{pH} \geq 5$. Perubahan warna signifikan menjadi warna merah menandakan bahwa buah memiliki rasa asam, apabila tusuk gigi tidak mengalami perubahan warna maka buah memiliki rasa manis.

\section{SARAN}

$$
\text { Dapat dilakukan pengujian }
$$
selanjutnya untuk mencari konsentrasi larutan antosianin yang sesuai sehingga perubahan warna dapat terlihat jelas serta mengembangkan alat indikator yang memiliki luas permukaan lebih kecil dalam pengujiannya.

\section{UCAPAN TERIMAKASIH}

Ucapan terimakasih penulis sampaikan kepada berbagai pihak yang telah membantu selama penelitian ini.

\section{DAFTAR PUSTAKA}

Agrianin, L. (2019). Potensi Ekstrak Bunga Telang (Clitoria Ternatea) Sebagai Pewarna Alami Lokal Pada Berbagai Industri Pangan. Canrea Journal, 2(1), 32 - 37.

Fanany, M. R. (2020). Ekstraksi Antosianin dari Bunga Telang (Clitoria Ternatea) dengan Metode Maserasi. Skripsi. Fakultas Teknologi Industri, Jakarta : Universitas Pertamina.

Humas Kementerian Koordinator Bidang Perekonomian RI. (2020). Pemerintah Gencarkan Konsumsi Buah Nusantara, Dorong Masyarakat Lebih Sehat di Masa Pandemi. Retrievedfrom https://ekon.go.id/publiksi/detail/448 /pemerintah-gencarkan-konsumsibuah-nusantara-dorong-masyarakatlebih-sehat-di-masa-pandemi

Ihsan, F., \& Wahyudi, A. (2010). Teknik Analisis Kadar Sukrosa Pada Buah Pepaya. Buletin Teknik Pertanian, 15(1), 10 - 12.

Mahmudastussa'adah, A. (2014). Karakteristik Warna dan Aktivitas Antioksisdan Antosianin Ubi Jalar Ungu. Jurnal Teknol dan Industri Pangan, 2 (25), 176 - 184.

Muzdalifah. (2012). Kajian Preferensi Konsumen Terhadap Buah-Buahan Lokal di Kota Banjarbaru. Jurnal Agribisnis Perdesaan, 2(4), 297 309.

Nurdayati, e. a. (2016). Klasifikasi Kematangan Buah Mangga Harum 
Manis Berdasarkan Normalisasi Warna Menggunakan Metode Fuzzy Logic Berbasis Web. Bogor : FMIPA, Universitas Pakuan.

Pracaya. (2011). Bertanam Mangga. Jakarta: Penebar Swadaya.

Priska, M., Peni, N., Carvallo , L., \& Ngapa, Y. D. (2018). Antosianin dan Pemanfaatannya. Cakra Kimia, 63 (2), 79 - 97.

Rachmayati. (2017). Pengaruh Tingkat Kematangan Buah Belimbing (Averrhoa carambola L.) dan Proporsi Penambahan Gula Terhadap Karakteristik Fisik, Kimia dan Organoleptik Jelly Drink Mengandung Karaginan. Jurnal Pangan dan Agroindustri, 5 (1), 49 60.

Kementerian Kesehatan RI. (2020). Pedoman Pencegahan dan Pengendalian Corona Virus Disease Covid-19. Jakarta : Direktorat Jenderal Pencegahan dan Pengendalian Penyakit.

Ritongga, R. P. (2021). Analisis Kesadaran Konsumen dalam Membeli Buah dan Sayur Melalui E-Commerce di Masa Pandemi Covid-19 (Kasus:ECommerce Buah dan Sayur di Kota Medan). Medan : Skripsi Program Studi Agribisni, Fakultas Pertanian Universitas Sumatera Utara.

Sudjatha, W., \& Wisaniyasa, N. W. (2017). Fisiologi dan Teknologi Pasca Panen (Buah dan Sayuran). Bali : Udayana University Press.

Supardan, D. (2020). Pelatihan Pembuatan Alat Deteksi Sederhana Boraks dan Formalin. Jurnal Pengabdian Masyarakat, 16 (2), 194 - 202.

Susanti, dkk. 2019. Pemanfaatan Ekstrak Kubis Ungu (Brassica Oleraceae) Sebagai Indikator Warna Pada Analisis Hidrokuinon. Akta Kimindo 4(2), 95 - 106
Yulianti. (2019). Analisis Kualitatif Boraks dalam Bakso dengan Indikator Alami Ekstrak Bunga Telang (Clitoria ternate L). Sainstech Farma, Vol 12 No. 1,13 - $166: 15$. 